\title{
STRUKTUR DASAR RING REFLEKSIF QUASI $\alpha$
}

\author{
Nofri Theofanya Larubun' ${ }^{1}$ E. R. Persulessy, S.Si, M.Si ${ }^{2}$ \\ ${ }^{1,2}$ Jurusan Matematika FMIPA, Universitas Pattimura \\ Jalan Ir. M. Putuhena, Ambon 97233, Indonesia \\ e-mail: ${ }^{1}$ fanylarubun@gmail.com; ${ }^{2}$ richardcalvin89@gmail.com
}

\begin{abstract}
Abstrak
Ide ring refleksif quasi $\alpha$ termotivasi dari ring rigid $\alpha$ dan perluasan sifat refleksif ke ring endomorfisma. Misalkan R suatu ring dan I $\subseteq \mathrm{R}$ merupakan Ideal di ring R. Ideal kanan I disebut refleksif jika untuk setiap $\mathrm{a}, \mathrm{b} \in \mathrm{R}$ berlaku $\mathrm{a} R \mathrm{~b} \subseteq \mathrm{I}$ maka $\mathrm{b} R \mathrm{a} \subseteq \mathrm{I}$. Kemudian dari homomorfisma ring terbentuk endomorfisma ring yaitu pemetaan inklusi dan jika pemetaan ini didefinisikan dengan $\alpha$ maka pemetaan ini disebut endomorfisma $\alpha$. Penulisan ini bertujuan untuk mempelajari struktur dasar ring refleksif quasi $\alpha$ yaitu elemen nilpoten dan kaitannya dengan ring rigid $\alpha$ dan ring refleksif. Jadi ring refleksif quasi $\alpha$ terbentuk dari struktur ring refleksif dan ring rigid $\alpha$.
\end{abstract}

Kata Kunci: ring refleksif, ring rigid $\alpha$, ring refleksif quasi $\alpha$

\section{BASIC STRUCTURE QUASI $\alpha$ REFLEXIVE RINGS}

\begin{abstract}
The quasi $\alpha$ reflexive rings idea is motivated from the rigid $\alpha$ rings and extension of the reflexive property to the endomorphism rings. Let $\mathrm{R}$ is a ring and $\mathbf{I} \subseteq \mathbf{R}$ is ideal of $\mathbf{R}$. A right ideal $\mathrm{I}$ of a ring $\mathrm{R}$ is called reflexive if for $\mathbf{a}, \mathbf{b} \in \mathbf{R}, \mathbf{a} \boldsymbol{R} \mathbf{b} \subseteq \mathbf{I}$ implies $\mathbf{b} \boldsymbol{R} \mathbf{a} \subseteq \mathbf{I}$. Then, from ring homomorphism, endormophism ring is formed, i.e inclusion mapping and if this mapping is defined by $\alpha$ then this mapping is called endomorphism $\alpha$. This research aims to study the basic structure of quasi $\alpha$ reflexive rings, namely the nilpotent element and their relation to rigid $\alpha$ rings and reflexive rings. So, the quasi $\alpha$ ring reflexive is formed the reflexive ring structure and the rigid $\alpha$ rings.
\end{abstract}

Keywords: reflexive rings, rigid $\alpha$ rings, quasi $\alpha$ reflexive rings

\section{Pendahuluan}

\subsection{Latar Belakang}

Matematika adalah ilmu yang mempelajari tentang besaran, struktur, ruang, dan perubahan. Di dalam matematika ada beberapa cabang ilmu, antara lain Statistika, Analisis, dan Aljabar. Aljabar adalah ilmu yang mempelajari tentang simbol-simbol matematika dan aturan-aturan untuk memanipulasi simbol-simbol tersebut. Matematika Aljabar tebagi lagi dalam beberapa bidang, antara lain Aljabar Elementer, Aljabar Linier, dan Aljabar Abstrak. Aljabar Abstrak adalah bidang subjek matematika yang mempelajari struktur aljabar, seperti grup, ring, medan, modul, ruang vektor dan aljabar medan.

Salah satu konsep aljabar abstrak yang telah dipelajari adalah grup. Suatu himpunan yang tidak kosong disebut grup jika himpunan tersebut dilengkapi operasi biner ' $*$ ' dan memenuhi aksioma-aksioma yang diberikan, diantaranya tertutup terhadap operasi ' $*$ ', asosiatif terhadap operasi ' $*$ ', mempunyai elemen netral terhadap operasi ' $*$ ', dan setiap elemen mempunyai invers terhadap operasi ' $*$ '. Kemudian, jika himpunan tidak kosong tersebut juga memenuhi aksioma komutatif terhadap operasi ' $*^{\prime}$ maka disebut grup abelian atau grup komutatif. Selanjutnya dari struktur grup di atas terbentuklah suatu himpunan yang disebut ring. Namun, sebenarnya Ring merupakan abstraksi dari himpunan bilangan bulat $\mathbb{Z}$. Ring merupakan Suatu himpunan tidak kosong yang dilengkapi dengan operasi ' $+{ }^{\prime}$ dan '.$'$ dan memenuhi sifat grup komutatif terhadap operasi $'+{ }^{\prime}$, semigrup terhadap operasi ${ }^{\prime} . '$, dan distributif terhadap operasi ${ }^{\prime}+{ }^{\prime}$ dan $^{\prime} \cdot{ }^{\prime}$. 
Di dalam struktur ring terdapat suatu elemen nilpotent, selanjutnya dari elemen nilpotent ini terbentuk suatu struktur baru yaitu ring tereduksi. Dari ring tereduksi ini diperluas lagi menjadi sifat refleksif pada ring. Di dalam struktur ring ada endormorfisma ring yang merupakan himpunan semua homomorfisma dari ring $R$ ke $R$ yang dinotasikan dengan $\operatorname{End}(R)$ dan jika pemetaan homomorfisma ini di simbolkan dengan $\alpha: R \rightarrow R$ maka pemetaan disebut endomorfsima $\alpha$. Dari endomorfisma $\alpha$ di bentuk lagi struktur baru yaitu ring $\alpha$-rigid sebagai perluasan dari ring tereduksi. Kemudian dari struktur $\alpha$-rigid dan sifat refleksif pada ring terbentukalah uatu struktur baru yaitu ring refleksif $\alpha$-quasi yang merupak perluasan dari ring $\alpha$-rigid dan sifat refleksif pada ring.

\subsection{Rumusan Masalah}

Berdasarkan uraian latar belakang diatas, maka masalah yang dibahas dalam penulisan ini adalah mengenai bagaimana Struktur Dasar Ring Refleksif $\alpha$-quasi ?

\subsection{Tinjauan Pustaka}

Istilah ring pertama kali diperkenalkan oleh John David Hilbert (1862-1943), namun pembahasannya sebatas pendekatan yang masih abstrak. Pada tahun 1981, Mason memperkenalkan ide dari sifat refleksif untuk ideal [2]. Kemudian pada tahun 1996, Krempa memperluas ide dari ring tereduksi menjadi ring endomorfisma [3].

Dalam buku " $A$ First Course In Abstract Algebra" oleh J.B. Frailegh (2000) membahas tentang ring namun belum membahas mengenai ring refleksif $\alpha$-quasi. Acuan utama pada penulisan ini adalah jurnal yang ditulis oleh Arnab Bhattacharjee (Arab Journal Of Mathematical Sciences, 2018) yang berjudul "An Extension Of The Reflexive Property Of Rings" [1].

Dengan menggunakan sumber utama diatas dan didukung oleh beberapa literatur yang lain, maka penulis mencoba menyusun penulisan tentang "Struktur Dasar Ring Refleksif $\alpha$-quasi" dengan harapan hasil dari penulisan ini mudah dipahami oleh para pembaca.

\subsection{Tujuan}

Berdasarkan uraian rumusan masalah diatas, maka tujuan dari penulisan ini adalah untuk mengetahui struktur dasar ring refleksif quasi $\alpha$.

\subsection{Landasan Teori}

Pada bagian ini akan dijelaskan teori-teori yang berhubungan dengan penulisan ini sehingga dapat dijadikan sebagai landasan berpikir dalam penulisan.

\subsubsection{Grup}

Diberikan $G \neq \varnothing$. Pada himpunan $G$ didefinisikan operasi biner ' $*$ '. Himpunan $G$ disebut grup terhadap operasi biner ' $*$ ' jika memenuhi sifat

$$
\begin{array}{ll}
\text { a. Tertutup }\left(\forall g_{1}, g_{2} \in G\right) g_{1} * g_{2} \in G \\
\text { b. Asosiatif }\left(\forall g_{1}, g_{2}, g_{3} \in G\right)\left(g_{1} *\right. \\
& \left.g_{2}\right) * g_{3}=g_{1} *\left(g_{2} * g_{3}\right) \\
\text { c. } & \text { Ada netral } \\
& (\exists e \epsilon G)(\forall g \in G) e * g=g * e=g \\
\text { d. } & \text { Setiap elemen mempunyai invers } \\
& (\forall g \in G)\left(\exists g^{-1} \in G\right) g * g^{-1}= \\
& g^{-1} * g=e
\end{array}
$$

Himpunan $G$ yang membentuk grup terhadap operasi biner ' $*$ ' yang didefinisikan padanya, dinotasikan dengan $(G, *)$.

\subsubsection{Grup Abelian}

Diberikan $(G, *)$ adalah grup. Himpunan $G$ disebut grup abelian jika memenuhi sifat komutatif, yaitu

\subsubsection{Semigrup}

$$
\left(\forall g_{1}, g_{2} \in G\right) g_{1} * g_{2}=g_{2} * g_{1}
$$

Diberikan $S$ adalah suatu himpunan tak kosong, $S$ disebut semigrup jika dalam $S$ didefinisikan suatu operasi biner' $*$ ' sedemikian sehingga

a. Tertutup $\left(\forall s_{1}, s_{2} \in S\right) s_{1} * s_{2} \in G$

b. Asosiatif $\left(\forall s_{1}, s_{2}, s_{3} \in G\right)\left(s_{1} * s_{2}\right) * s_{3}=$ $s_{1} *\left(s_{2} * s_{3}\right)$

\subsubsection{Ring}

Diberikan himpunan $R \neq \emptyset$. Pada $R$ didefinisikan operasi-operasi biner penjumlahan ' + ' dan pergandaan ' $\cdot$ '. Himpunan $R$ disebut ring terhadap operasi penjumlahan ${ }^{\prime}+{ }^{\prime}$ dan pergandaan ${ }^{\prime} \cdot{ }^{\prime}$ jika memenuhi sifat
a. $\quad(R,+)$ merupakan grup komutatif
b. $(R, \cdot)$ merupakan semigrup
a. Tertutup $(\forall a, b \in R) a \cdot b \in R$
b. Asosiatif $(\forall a, b, c \in R)(a \cdot b)$. $c=a \cdot(b \cdot c)$
c. $\quad(R,+, \cdot)$ bersifat distributif
i. Distributif Kiri $(\forall a, b, c \in R) a$. $(b+c)=a \cdot b+a \cdot c$
ii. Distributif Kanan $(\forall a, b, c \in R)(a+b) \cdot c=a$. $c+b \cdot c$

\subsubsection{Contoh}


Himpunan $(\mathbb{Z},+, \cdot),(\mathbb{Q},+, \cdot),(\mathbb{R},+, \cdot),(\mathbb{C},+, \cdot)$ merupakan ring.

Matriks $M_{2 \times 2}(\mathbb{R})$ merupakan ring terhadap operasi penjumlahan dan pergandaan.

\subsubsection{Ideal}

Misalkan $R$ suatu ring tak nol dan $I$ adalah himpunan bagian tak kosong di $R$. Himpunan $I$ disebut Ideal dari $R$ jika

$$
\begin{array}{ll}
\text { i. } & \left(\forall s_{1}, s_{2} \in I\right) s_{1}-s_{2} \in I \\
\text { ii. } & (\forall r \in R)\left(\forall s_{1} \in I\right) r s_{1}, s_{1} r \in I
\end{array}
$$

\subsubsection{Ideal Kiri dan Ideal Kanan}

Misalkan $R$ suatu ring dan $I \subseteq R$.

i. $\quad$ Subset $I$ disebut ideal kiri jika

a. $\left(\forall s_{1}, s_{2} \in I\right) s_{1}-s_{2} \in I$

b. $(\forall r \in R)\left(\forall s_{1} \in I\right) r s_{1} \in I$

ii. Subset $I$ disebut ideal kanan jika

a. $\left(\forall s_{1}, s_{2} \in I\right) s_{1}-s_{2} \in I$

b. $(\forall r \in R)\left(\forall s_{1} \in I\right) s_{1} r \in I$

\subsubsection{Ring Refleksif}

Misalkan $R$ suatu ring dan $I \subseteq R$ merupakan ideal di ring $R$. Ideal kanan $I$ disebut refleksif jika untuk $a, b \in R$ berlaku $a R b \subseteq I$ maka $b R a \subseteq I$.

\subsubsection{Ring Reversibel}

Diberikan ring $R$. $R$ disebut reversibel jika untuk setiap $a, b \in R, a b=0$ maka $b a=0$

\subsubsection{Elemen Nilpoten}

Diberikan ring $R$. Elemen $x \in R$ disebut elemen nilpoten jika terdapat $n \in \mathbb{N}$ sedemikian sehingga $x^{n}=0$

\subsubsection{Ring Tereduksi}

Ring $R$ disebut ring tereduksi jika tidak memiliki elemen nilpoten yang tidak nol.

\subsubsection{Homomorfisma Ring}

Diberikan ring $\left(R_{1},+_{1},{ }_{1}\right)$ dan $\left(R_{2},+_{2},{ }_{2}\right)$ serta suatu pemetaan $f: R_{1} \rightarrow R_{2}$. Pemetaan $f$ disebut homomorfisma ring jika memenuhi

$$
\begin{array}{ll}
\text { a. } & f\left(x+{ }_{1} y\right)=f(x)+{ }_{2} f(y) \\
\text { b. } & f(x \cdot 1 y)=f(x) \cdot \cdot_{2} f(y)
\end{array}
$$

\subsubsection{Contoh}

Diberikan ring

$$
T_{2 \times 2}(\mathbb{Z})=\left\{\left[\begin{array}{ll}
a & b \\
0 & c
\end{array}\right] \mid a, b, c \in \mathbb{Z}\right\}
$$

Terhadap operasi penjumlahan dan perkalian matiks. Didefinisikan pemetaan

$$
f: T_{2 \times 2}(\mathbb{Z}) \rightarrow \mathbb{Z}
$$

yaitu untuk setiap $\left[\begin{array}{ll}a & b \\ 0 & c\end{array}\right] \in T_{2 \times 2}(\mathbb{Z})$,

$f\left(\left[\begin{array}{ll}a & b \\ 0 & c\end{array}\right]\right)=a$.

\section{Hasil dan Pembahasan}

Berdasarkan definisi-definisi diatas maka diperkenalkanlah ide ring refleksif quasi $\alpha$ sebagai perumuman dari ring rigid $\alpha$ dan sifat refleksif endomorfisma ring.

\subsection{Sifat Refleksif}

Suatu relasi disebut refleksif jika setiap unsur dalam himpunan tersebut berelasi dengan dirinya sendiri.

$$
(\forall a \in A) a \mathrm{R} a
$$

\subsection{Operasi Biner}

Operasi Biner adalah operasi yang melibatkan dua elemen, elemen tersebut bisa sama maupun berbeda.

Operasi Biner merupakan fungsi maka dapat dikatakan operasi biner juga merupakan relasi.

Operasi Biner pada ring adalah Penjumlahan "+" dan Pergandaan “*”

\subsection{Ring Refleksif Quasi $\alpha$}

Endomorfisma $\alpha$ dari ring $R$ disebut refleksif quasi kanan jika untuk $a, b \in R, a R \alpha(b)=0$ maka $b R \alpha(a)=0$. Endomorfisma $\alpha$ dari ring $R$ disebut refleksif quasi kiri jika untuk $a, b \in R$, $\alpha(a) R b=0$ maka $\alpha(b) R a=0$

\section{Proposisi 2.4}

Diberikan $R$ adalah ring terduksi. Maka

$$
S=\left\{\left(\begin{array}{ll}
a & b \\
0 & a
\end{array}\right): a, b \in R\right\}
$$

adalah ring refleksif $\alpha$-quasi dimana $\alpha: S \rightarrow S$ didefinisikan oleh

$$
\alpha\left(\left(\begin{array}{ll}
a & b \\
0 & a
\end{array}\right)\right)=\left(\begin{array}{cc}
a & -b \\
0 & a
\end{array}\right) .
$$

\section{Proposisi 2.5}


Diberikan $R$ ring refleksif dan endomorfisma $\alpha$ : $R \rightarrow R$. $R$ adalah ring refleksif quasi $\alpha$ kanan jika dan hanya jika quasi $\alpha$ kiri

\subsection{Contoh}

Andaikan ring $R=\mathbb{Z}_{2} \oplus \mathbb{Z}_{2}$ dengan operasi penjumlahan dan pergandaan.

Misalkan $\alpha: R \rightarrow R$ endomorfisma yang di definisikan oleh

$$
\alpha((a, b))=(b, a)
$$

Tunjukan bahwa ring $R$ merupakan ring refleksif quasi $\alpha$

\subsection{Contoh}

Misalkan $S$ ring refleksif. Andaikan $R=U_{2}(S)$.

Misalkan $\alpha: R \rightarrow R$ endomorfisma yang

didefinisikan oleh

$\alpha\left(\left(\begin{array}{ll}a & b \\ 0 & c\end{array}\right)\right)=\left(\begin{array}{ll}a & 0 \\ 0 & 0\end{array}\right)$.

Tunjukkan bahwa ring $R$ merupakan ring refleksif quasi $\alpha$.

\section{Kesimpulan}

Berdasarkan hasil penulisan ini, dapat disimpulkan bahwa suatu himpunan yang tidak kosong yang dilengkapi dengan operasi biner dan memenuhi ke sembilan aksioma disebut ring refleksif quasi $\alpha$ jika terdapat suatu pemetaan homomorfisma inklusi atau dengan kata lain endomorfisma, memenuhi sifat refleksif quasi $\alpha$ kiri sekaligus sifat refleksif kuasi $\alpha$ kanan.

\section{Saran}

Adapun saran penulis untuk peneliti selanjutnya adalah untuk meneliti lebih lanjut tentang Ring Refleksif Quasi $\alpha$ seperti kaitan ideal kiri dengan sifat refleksif pada ring karena yang dibahas dalam penulisan ini hanya kaitan ideal kanan dengan sifat refleksif pada ring.

\section{Daftar Pustaka}

[1] A. Bhattacharjee, "An Extension of the Reflexive Property of Rings," ARAB JOURNAL OF MATHEMATICAL SCIENCES, 2018.

[2] G. Mason, Reflexive Ideals, Comm Algebra, 1981, pp. 1709-1724.
[3] J. Krempa, Some Examples of Reduced Rings, J. Pure Appl Algebra, 1996, pp. 289-300.

[4] Y. L. T. K. Kwak, Reflexive Property of Rings, 2012, pp. 1576-1594.

[5] Y. L. S. Y. T. K. Kwak, Reflexive Property Skewed by Endomorphisms, 2014, pp. 217-234.

[6] Sri Wahyuni, Teori Ring dan Modul, Gadjah Mada University Press, 2016. 